\title{
An investigation into the role of human capital competences and their pay-off
}

Citation for published version (APA):

Heijke, J. A. M., Meng, C. M., \& Ramaekers, G. W. M. (2002). An investigation into the role of human capital competences and their pay-off. Researchcentrum voor Onderwijs en Arbeidsmarkt, Faculteit der Economische Wetenschappen. ROA Research Memoranda No. 3E https://doi.org/10.26481/umaror.200203E

Document status and date:

Published: 01/01/2002

DOI:

10.26481/umaror.200203E

Document Version:

Publisher's PDF, also known as Version of record

\section{Please check the document version of this publication:}

- A submitted manuscript is the version of the article upon submission and before peer-review. There can be important differences between the submitted version and the official published version of record.

People interested in the research are advised to contact the author for the final version of the publication, or visit the DOI to the publisher's website.

- The final author version and the galley proof are versions of the publication after peer review.

- The final published version features the final layout of the paper including the volume, issue and page numbers.

Link to publication

\footnotetext{
General rights rights.

- You may freely distribute the URL identifying the publication in the public portal. please follow below link for the End User Agreement:

www.umlib.nl/taverne-license

Take down policy

If you believe that this document breaches copyright please contact us at:

repository@maastrichtuniversity.nl

providing details and we will investigate your claim.
}

Copyright and moral rights for the publications made accessible in the public portal are retained by the authors and/or other copyright owners and it is a condition of accessing publications that users recognise and abide by the legal requirements associated with these

- Users may download and print one copy of any publication from the public portal for the purpose of private study or research.

- You may not further distribute the material or use it for any profit-making activity or commercial gain

If the publication is distributed under the terms of Article $25 \mathrm{fa}$ of the Dutch Copyright Act, indicated by the "Taverne" license above, 


\title{
An investigation into the role of human capital competences and their pay-off
}

\author{
ROA-RM-2002/3E
}

Hans Heijke, Christoph Meng, Ger Ramaekers

Research Centre for Education and the Labour Market

Faculty of Economics and Business Administration

Maastricht University

Maastricht, November 2002 
ISBN 90-5321-346-5

Sec02.188.doc 


\section{Contents}

Page

Abstract

1 Introduction 1

2 The data $\quad 7$

3 A first descriptive look at three different types of human capital 10

4 The direct pay-off of human capital competences: A general wage regression

5 The indirect pay-off of human capital competences

6 Conclusions

References 



\begin{abstract}
Learning is possible both in school and later on when working. The learning process is thereby dependent on the context wherein it takes place. This implies that in particular three groups of competences can be distinguished. First of all, competences acquired in school, which are of direct use in later work, secondly, competences acquired in school, which facilitate acquiring new competences after graduation from school and finally, competences acquired mainly in a working context. Using a unique dataset on Italian university graduates, the target of this paper is to show that these three competences can indeed be distinguished and to discuss their different roles and pay-offs in the labour market.

We will show that, firstly, the level of field-specific skills obtained in higher education offers graduates a comparative advantage when working inside the own field-specific domain and therefore has a pay-off for those graduates who are able to find a job in their own fieldspecific domain; secondly, that management skills are valued in the labour market but seem to be more effectively acquired in a working context than in higher education and thirdly, that general academic competences acquired in higher education do not pay off directly but have a significant supportive role when learning skills that have a direct pay-off in the labour market but are more effectively acquired outside education.
\end{abstract}

Keywords: Human capital formation, Human capital competences, Wage effects of competences

JEL Classification: J24, J31, J41 



\section{Introduction}

There are several well-known reasons to transfer the generation of knowledge and skills partially from the initial schooling phase to the working life later on. One of them is the uncertain future application possibility of specific knowledge and skills obtained during the educational career. Another reason is that some groups of knowledge and skills can be generated more efficiently in a context combining working and learning or, in general terms, when one possesses more life experience. Considering this transfer, one has to take into account that the effectiveness of a postponed learning process is partially determined by the amount of knowledge and skills obtained during the initial schooling. To get insight in what can be learned efficiently in the initial schooling and what can be generated better in the post-initial phase, it is of importance to analyze the type of knowledge and skills to be considered and how they are related to each other through the process in which they are generated and used. In this paper, using an explorative study, we try to gain insight into the different roles and the pay-off of three specific groups of skills: field-specific skills as an example of skills that can be learnt effectively in initial education, management skills as an example of skills to be acquired in a working context and academic skills as an example of skills that improve the learning process in initial education or in later training. To start with, a short literature review shall provide some insight into the research done so far and the criticism on it.

\section{A brief literature review}

Changes in the modern workplace, brought about by technology, management innovations, and increased competition in the global marketplace, have led to many concerns about the adequacy of workforce skills (Stasz, 1998, p.187). Discussions on this problem often emphasize the importance of certain skills and blame the educational system for inadequately providing them. Labour market parties thereby too easily relate the skills needed to function in a job and to achieve a high salary with what initial education should generate. This is the idea one gets when looking at studies (see for instance Bishop, 1995) in which the central question is whether general skills or rather occupation-specific skills pay off on the labour market. In the current debate on occupation-specific versus general education and training, Bishop ${ }^{1}$ (1995) strongly advocates that education should focus on occupation-specific skills rather than on general academic skills. According to Bishop, "research shows that productivity derives directly from social abilities (such as good work habits and people skills) and cognitive skills that are specific to the job and occupation, not from reading, writing, and mathematics skills". Bishop hereby departs from the premise that academic skills are mere tools for developing specific skills but not a good substitute for occupation-specific skills. "While learning a new skill is easier when the worker has good basic skills, a foundation of job knowledge and occupational skills is usually even more essential," according to Bishop. In an earlier article, Bishop and Kang (1989) argue that for high school graduates who enter the labour market vocational and academic education in high school are complements rather than substitutes. They found that students, who took

1. Bishop uses US-data on high school graduates in the 1980's. 
four full-year vocational courses and eight full-year academic courses in their final three years, earned substantially more, immediately after graduating, than students who took 12 academic courses ${ }^{2}$ (Kang \& Bishop, 1989). The more recent research literature (e.g. Campbell and Laughlin, 1991) also tends to find stronger positive effects of vocational course work on labour market outcomes (For an overview of research, see Mane, 1998). In assessing the effects of high school curricula on later success in the labour market, Altonji (1995, p. 409) found "that the return to additional courses in academic subjects is small", while Mane (1998, p. 3) states that "holding past and present school attendance and a host of other variables constant, academic course work in high school had much smaller labour market payoffs than vocational course work."

While Bishop stresses the importance of occupation-specific skills, other authors underline the importance of general (or generic) skills. Stasz et al. (1993) state that "Employers and workers note the need for generic skills, such as problem solving, communication and the ability to work in teams. Furthermore, Duncan (1968) already mentioned that "Verbal and quantitative skills are especially significant outcomes of higher education, not only because they are valuable in their own right but also because they facilitate learning of all kinds in college and throughout life." In line with this, Bowen (1977, p. 89) sees that "the important substantive aims of higher education do lie in the realm of residues ... [and that] ...the residues also consist of the skills and perspectives that enable students in later life to learn or relearn detailed knowledge in a variety of fields as occasion demands and to fit this knowledge into a framework of larger principles and concepts. Linked to this is the argument that technological change influences the rate at which human capital becomes obsolete and also increases the uncertainty associated with human capital investments. As a consequence, training may increase or decrease at higher rates of technological change (Bartel \& Sicherman, 1998, p. 718). Economic theory, however, does not provide a clear prediction of the sign of the relationship between technological change and investments in training. One argument is that technological change makes formal education and previously acquired skills obsolete. In accordance with this view, technological change should spread investment in human capital, thus increasing investment in on-the-job training and reducing investment in formal education. The alternative view, put forward by Welch (1970), is that general education enables workers to adjust to and benefit from technological change. In this view workers should invest more in schooling and rely less on specific on-the-job training (Bartel \& Sicherman, 1998, p. 719).

As discussed above, technological change also increases the uncertainty associated with human capital investments. However, the effect of uncertainty on investments in human capital depends on the kind of human capital (Levhari \& Weiss, 1974). More general types of human capital (for instance general education) may facilitate adjustment to future shocks. Hence, investments in more general human capital would increase, while investments in

2. Although vocational courses showed a better pay-off for high school graduates entering the labour market, complete specialization in vocational courses and ignoring training in basic skills would not be as effective as a curriculum of courses providing both vocational and basic skills, according to the authors. 
more specific types of human capital would decrease. The reason is that the variance of the returns to general human capital decreases while the variance of the returns to specific human capital increases (under standard assumptions, such as risk aversion of workers).

In deriving skills to be taught in initial education from the skills required in the work place, important points are often neglected. Firstly, the notion that some skills are acquired more efficiently in combination with work than in a purely educational context. In this respect, Becker (1962) already argued in the early sixties that 'some types of knowledge can be mastered better if simultaneously related to a practical problem; others require prolonged specialization. That is, there are complementarities between learning and work and between learning and time'. (Becker, 1962, p.25.) According to Ducatel (1998), effective learning takes place through a combination of formal learning (which is mainly codified) and experiential learning (which is mainly tacit). Ducatel further argues that in order to create an appropriate mix of specific skills and more general competencies, the formation of knowledge in formal and experience-based contexts should interact and overlap. In line with this, Green, Ashton, and Felstead (2001) state that 'a growing body of research from labour economists, sociologists, and management studies has recently provided an alternative perspective on the source of skills, stressing the indispensability of work-based learning' (for an overview see Green et al. 2001, p. 410). Furthermore, Heijke and Ramaekers (2001) state on the basis of an analysis of the labour market position of economics and business administration graduates that it seems very difficult for initial university education to generate the skills that are required for managerial leadership. Since most of these skills are predominantly acquired through work, a combination of working and learning seems more effective, indicating that one cannot derive directly from the wage rate paid the competences that initial education should teach. In line with this, Van der Sluis (2000) points at the growing debate as to the effectiveness of learning management skills 'off the job'.

The second point of neglect is the notion that education is the best place to generate skills needed to improve the efficiency with which additional skills can be generated later on. In general, more educated workers train more because the available human capital is an input in the production of new human capital or because individuals who are better 'learners' will invest more in both schooling and training (Bartel \& Sicherman, 1998, p. 720). This is in line with one of the main findings of van Smoorenburg and van der Velden (2000) that 'as expected, a higher educational level results in a higher probability of participation in firm training' (p.213). According to Stasz (2001) 'formal education is provided through compulsory schooling, and it is generally accepted that schooling should impart some modicum of formal knowledge that will serve as the foundation or building blocks for future learning in school and life' (p. 389). With respect to the above controversy between general and specific skills, Johnson (1979) also assumes a twofold interaction between general and specific skills: 'general education partially replaces specific skills and, like ability, reduces the costs of obtaining specific skills'.

The third point relates to the data availability. As a consequence, educational indicators (such as tenure, grades, courses) are often used as proxies for a worker's available skills. However, in today's knowledge economy with its emphasis on continuous learning, these 
kinds of indicators are no longer sufficient for measuring or predicting career success. Allen and van der Velden (2001) found that "[the findings]...establish beyond reasonable doubt the importance of the distinction between schooling and skills ... [and]...contrary to the assumptions of assignment theory however, educational mismatches are neither a necessary nor a sufficient condition for skill mismatches" (p. 449). This argument is also in line with Heijke, Koeslag, and van der Velden (1998). Furthermore, approaching the topic by usage of courses, one has to be careful with direct conclusions on general academic skills and field-specific skills. For instance, Green (1998), Stasz (2001), Green et al. (2001), McIntosh and Vignoles (2001), and Shaughnessy, Levine and Cappelli (2001) have done research into the labour market value of particular work skills, which can be seen as a more accurate and reliable way for estimating individual labour market capacities. In line with this, Heijke and Ramaekers (1998) elaborated on the labour market importance of particular types of knowledge and skills of economics graduates. Furthermore, Heijke, Koeslag, and van der Velden (1998) explored to what extent experienced deficiencies in the preparation for occupations with respect to both the more generic and the more occupation-specific skills affect the earnings level in the labour market.

\section{Hypotheses and set-up}

In this paper, we will follow in particular the line of research as set out by Green (1998), and Heijke and Ramaekers (1998) and try to gain insight into the role of three types of skills in the labour market, namely field-specific skills, management skills, and general academic skills, and their pay-off. Before discussing the actual setting and the hypotheses to be tested, we will state some theoretical notions, firstly with respect to the labour market and secondly with respect to the process of generating human capital competences in the higher education system, thus creating the theoretical context of this analysis.

According to the human capital theory - which focuses on characteristics of the worker talent, education and experience determine the worker's performance in the job, and hence the wage rate (Becker, 1964). For a broad outline of the human capital theory, see Schultz (1961). By contrast, in the labour queue theory or the job competition model (Thurow, 1975), wages are predominantly determined by characteristics of the job. According to this theory, characteristics of the worker are only relevant in the selection process. The more education the worker possesses, the lower the costs of training that is necessary for good job performance.

However, if we want to examine the relationship between education and the labour market these theories only offer a one-sided framework. Both the human capital theory and the labour queue theory lack the interaction between characteristics of the worker and characteristics of the job. The assignment theory (for an overview, see Sattinger, 1993) takes explicit account of this interaction by addressing the issue whether the applicability of a person's knowledge and skills is context-specific. This theory shows how heterogeneous individuals are allocated to jobs that require varying qualifications on the basis of the qualifications that they possess. It is assumed that the knowledge and skills which individuals possess give them comparative advantages in certain types of occupations. 
Hence, graduates of some fields of education have better job opportunities in occupations strongly related to their field of education (Hartog, 1992).

University education is organized around disciplines. However, in university education students acquire not only field-specific knowledge and skills but also general academic knowledge and skills. ${ }^{3}$ General academic knowledge and skills are needed to acquire a coherent body of field-specific knowledge. Vice versa, by learning field-specific knowledge, students also acquire general academic knowledge and skills, which in turn increase the effectiveness of the learning process through which field-specific knowledge and skills are acquired. Furthermore, general academic knowledge and skills not only further the acquisition of field-specific knowledge and skills, but also foster the development of other skills valued in the labour market (e.g. management skills).

The theoretical arguments on the generation process of human capital competences in higher education are illustrated in a simplified manner in Diagram 1.

Diagram 1

Generation of knowledge and skills in higher education

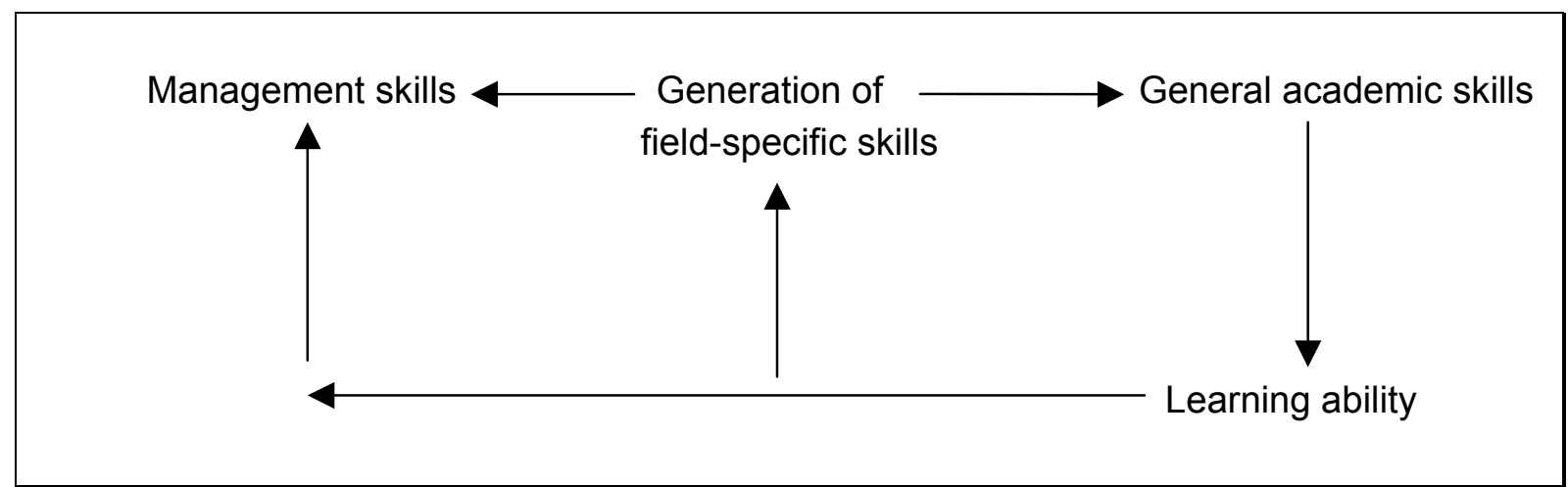

So far, the theoretical arguments put forward the idea that 'general academic competences' acquired during one's university education are a solid base, which facilitates the additional generation of skills later on, including 'management competences'. Hence, and in line with some of the literature discussed above, academic skills are indirectly of crucial importance, as they increase the effectiveness with which occupation-specific skills are generated or maintained, thereby reducing training costs. Furthermore, the study assumes that fieldspecific skills pay off under the condition that the job taken is within the domain of the study. Analyzing the process of generation, use and pay-off of knowledge and skills, we expect to gain a better insight into the importance of the different stages in the generation of skills related to the productive capacity of individuals.

In an explorative way, we will discuss to what extent these theoretical notions can be found back in practice. For this reason, unique data on Italian higher education graduates will be analyzed. These data contain information on the graduates' educational careers, the skills

3. For an overview of possible patterns of core skills and generic skills provision in higher education, see Bennett, Dunne and Carré (1999). 
generated, the working careers and positions on the labour market three years after graduation (including wage and training activities), and the actual use of skills. Data on the later stages of the careers are not available.

On the basis of the theoretical notions on the labour market and on the generation of human capital competences in higher education, as illustrated in Diagram 1, we are in particular interested in the return of human capital competences on the labour market during the transition period from school to work. For that reason, we follow the job-matching theory, by incorporating in the analyses both the knowledge and skills of the graduate and the knowledge and skills that are required in his job. In view of the job-matching theory, it may be expected that graduates put their knowledge and skills into use where they generate the highest productive value and hence the highest wages. Of particular interest in our analysis are two characteristics of jobs: working in one's own field-specific domain or working outside the fieldspecific domain and holding a management position or not holding a management position.

Combining the theoretical notions with respect to the adjustment theory with the distinction of competencies made and the characteristics of the occupation, we intend to discuss the following hypotheses:

- Working inside one's field-specific educational domain creates a comparative advantage. Hence, field-specific knowledge and skills obtained during higher education is of higher productive value inside one's field-specific educational domain.

- Management skills obtained during higher education or at work are of direct productive value. Management skills are learned more efficiently within the context of work than in a purely educational context.

- General academic skills are indirectly of crucial importance to increase the effectiveness with which knowledge and skills are generated and maintained.

The structure of the paper is as follows. In Section 2, we describe the data that were used for this paper, the concepts and their operationalisation, and we characterize the graduates by their personal characteristics, educational attainments, and several job-related characteristics.

Section 3 will provide a first explorative look at human capital competences. Hence, we will turn our attention to the amount of 'general academic competences', 'field-specific competences' and 'management competences' built up during the university education and to the level at which these competences are required within the actual working situation (measured three years after graduation). Consequently, Section 3 will focus on the differences between supervisory and non-supervisory jobs and on the differences between jobs inside one's field-specific domain and outside one's field-specific domain.

In Section 4, a general wage regression will be analyzed to measure the extent of the direct pay-off of human capital competences, as they are required in the current job, while in Section 5 the indirect pay-off of human capital competences obtained during higher education will be discussed. The paper will be concluded in Section 6 by a summary of the main findings and a look at further possible and necessary research. 


\section{The data}

The research data for this paper were obtained from a postal survey among 1994/1995 higher education graduates from 11 European countries, carried out in 1998 within the context of the EU's Targeted Socio-Economic Research (TSER) programme. In this paper, we will concentrate on the results found for Italian university graduates, in particular those from Northern Italy. ${ }^{4}$ We concentrate on Italian graduates because clear information is available for them with respect to possible management positions. Although formal education in Italy has always been organized at the national level, school quality and the state of the labour market show significant regional differences. In combination with a substantial immobility of the resident population (according to Brunello, Comi and Lucifero, 2000 , regional out/inflows are less than one percent of the regional population), this indicates that the regional situation may differ considerably, in particular between the North and the South of Italy. ${ }^{5}$ As our target is not to explain regional differences in Italy, we will restrict our analysis to the Northern part of Italy.

Since the survey is held some three years after graduation, the study observes graduates at the beginning of their professional career. In total, 2,318 Italian graduates responded to this survey. However, this paper covers only 734 graduates. The reason is that the paper will only include graduates for whom salary data are available, who are at least working 12 hours a week on their main working assignment and, as indicated above, are employed in the Northern part of Italy. All respondents covered in this paper completed degree courses (corsi di laurea), which make up the bulk of higher education in Italy (there are currently 88 different types of degree courses). Table 1 characterizes the paid working graduates by a number of variables that are relevant for this paper.

The largest percentage of the respondents works in the region of Lombardia $(43.2 \%)$, followed by Veneto $(18.3 \%)$ and Piemonte $(12.4 \%){ }^{6}$ With respect to the field of study ${ }^{7}$, the table shows that most respondents have a major in engineering $(21.8 \%)$, followed by business $(20.4 \%)$ and arts \& humanities (18.3\%).

Table 1 also shows that a small majority of the respondents is male and that the graduates are on average 31 years old at the time of the survey (about three years after graduation). Apart from their formal qualification (the university education), $45.3 \%$ of the graduates have gained additional qualifications by participating in further training after their graduation. With respect to three specific kinds of training, we see that after graduation, $15.7 \%$ of the graduates have followed training covering cross-disciplinary scholarly knowledge, $4.5 \%$ followed training in new scholarly knowledge in their discipline, and $6.8 \%$ of the graduates

4. Graduates/Employees from the following Italian Regions are included: 'Trentino-Alto Adige', 'FriuliVenezie-Giuli', 'Lombardia', 'Valle d'Aosta', 'Piemonte', 'Veneto', 'Liguria', Emiglia-Romagna'.

5. Preliminary analysis has established considerable differences between different regions of Italy.

6. From the total of 734 respondents analyzed in this paper, only $10(1.2 \%)$ studied in a region outside the ones considered here as Northern Italy.

7. The distinction between the different fields of study is as given in the data. 
followed training in management/leadership competences. At the time of the survey, most graduates had a full-time and permanent working contract, a job that matched their educational level ${ }^{8}(64.0 \%)$ and a job in their own domain ${ }^{9}(76.6 \%)$. About one out of three worked $(35.7 \%)$ in a supervisory job. ${ }^{10}$

Table 1

Characteristics of respondents, working within a paid job for a least 12 hours a week

Current region of employment

Piemonte

Valle d'Aosta

Liguria

Lombardia

Trentino-Alto Adige

Veneto

Friuli-Venezia Giulia

Emilia-Romagna

Personal Characteristics

Gender: male

Average age at time of survey (1998)

Field of study

Arts \& Humanities

Social Sciences

Business

Law

Natural Sciences

Engineering

Health

Job characteristics

Permanent contract

Full-time contract (at least 32 hours)

Job at university level

Job in own domain

Supervisory job

Average number of weekly working hours

Average gross hourly wage (Euros)

Working for a private employer

Training after graduation

Further training followed after graduation

Training in cross-disciplinary knowledge

Training in field-specific knowledge of own study field

Training in management
$12.4 \%(91)$

$0.5 \%(4)$

$4.0 \%(29)$

$43.2 \%(317)$

$1.6 \%(12)$

$18.1 \%(133)$

$11.3 \%(83)$

$11.3 \%(83)$

$52 \%(382)$

31.02 years (s.d. 3.45$)$

$18.3 \%(134)$

$11.9 \%(87)$

$21.4 \%(157)$

$6.7 \%(49)$

$12.1 \%(89)$

$21.8 \%(160)$

$7.9 \%(58)$

$79.5 \%(543)$

$83.9 \%(616)$

$64.0 \%$ (465)

$76.6 \%(562)$

$35.7 \%$ (262)

36.37 (s.d. 6.89)

11.08 (s.d. 9.3)

$69.4 \%$ (509)

$45.3 \%$ (319)

$15.7 \%(115)$

$4.5 \%(33)$

$6.8 \%(50)$

8. Job at university level is measured as job for which at least an education on a university level is required.

9. Job in own domain is measured as holding a position for which the own field of study is by far the best field or for which a related field of study could prepare as well.

10. The distinction between supervisory and non-supervisory jobs is based on the question if the graduate's current job position is classified as top- or middle- level management (supervisory jobs) or as low-level management or professional without management tasks (non-supervisory jobs). 
In what follows, we will have a look at the operationalisation of the data and in particular at the three different kinds of human capital distinguished in the theoretical model: general academic skills, field-specific skills and management skills.

The data provide a list of 36 competences representing demands for knowledge and skills. The graduates could indicate for each competence the extent to which they possessed that particular competence at the time of graduation and the extent to which that particular competence is required in their current job. ${ }^{11}$ Both the extent to which they possessed it and the extent to which it is required in the current job were measured on a 5-point scale, ranging from 1 ("not at all") to 5 ("to a very high extent"). In the first step, using a hierarchical clustering method, eight different clusters of knowledge and skills, measured as possessed by the students at the time of graduation, have been distinguished.

In this paper, we will concentrate on three of these eight clusters, representing general academic skills (as an example of skills improving the learning process in initial education and in later training), field-specific skills (as an example of skills learnt most efficiently in initial education) and management skills (as an example of skills learnt most efficiently in a context combining work and education). For that reason, for each of the graduates an average of the skills possessed at the time of graduation and of the skills required in the current job was calculated for the following three clusters:

\section{General Academic Skills}

- Broad general knowledge

- Cross disciplinary thinking/knowledge

- Problem-solving ability

- Analytical competences

- Reflective thinking, assessing one's work

- Learning abilities

- Power of concentration

- Critical thinking

- Written communication skills

2. Field specific skills

- Field-specific theoretical knowledge

- Field-specific knowledge of methods

3. Management skills

- Planning, coordinating and organizing

- Leadership

- Economic thinking

- Creativity

11. According to Spenner (1990, p.416),'self-report measures offer characteristic strengths and weakness for skills measurements, similar to other types of self-report measurement. There is no systematic evidence that people seriously distort reporting of their job characteristics; to the contrary, most of the evidence suggests that people, by and large, are fairly accurate perceivers and reporters of their immediate job situation.' 
- Oral communication skills

- Tolerance, appreciating of different points of view

- Initiative

- Taking responsibilities, decisions

The findings of Quinn et al. (1990) support our grouping of competences into the management cluster. According to Quinn et al. (1990, p.21), it may be expected that the following directive competences (leadership, initiative), coordinative competences (planning and organizing), innovative competences (creativity, taking decisions) and human relations competences (oral communication skills, appreciating of different points of view) are of crucial importance for managerial leaders. Furthermore the internal consistency of the clusters is also supported by Cronbach alpha. ${ }^{12}$ For the cluster of 'general academic skills' we find a Cronbach alpha of 0.80 when measured at the time of graduation, or 0.85 when measured at the time of survey. For the cluster of 'field-specific skills' the alphas are 0.75 and 0.83 , and for the cluster of 'management skills' 0.75 and 0.83 , respectively.

\section{A first descriptive look at three different types of human capital}

In this section we will have a first descriptive look at the three different types of human capital distinguished in this paper. We focus our attention on the level of competences built up during one's university education and to the level of competences required within the actual working situation (measured three years after graduation). This section focuses on differences between supervisory (position in top-level or middle-level management), and non-supervisory (low-level management or professional without management tasks) jobs and on the differences between jobs inside one's field-specific domain and outside one's field-specific domain. The grouping of low-level managers into the class of non-supervisory jobs is based on the fact that preliminary analysis of the data, in particular with respect to the different management competences, did not produce any significant differences between low-level managers and professionals without management tasks. On the other hand, there are clear differences between low-level management on the one side and middle- and toplevel management on the other. ${ }^{13}$

Our theoretical argumentation puts forward that within the educational sector, a symbiotic process takes place in which driven by 'field-specific knowledge and skills', also 'general academic skills' and 'management skills' are acquired. We would therefore expect to find a positive correlation between the different types of competences. The following table shows the correlations between the competences (measured at the time of graduation). The positive and significant (on a 1\% level) correlations indicate that within the university education process, a symbiotic situation emerges between the three different types of competences. The strongest correlations are found between 'general academic skills' and

12. Although there is no generally agreed cut-off, usually a value of alpha of 0.7 or more is seen as acceptable (Nunnually, 1978)

13. Data not shown in this paper. 
'management skills' and between 'general academic skills' and 'field-specific skills', which supports our view on the generation process of human capital competences in higher education (see Diagram 1).

Table 2

Correlation matrix of the three types of competences possessed at the time of graduation

General academic skills Field-specific skills Management skills

$\begin{array}{llll}\text { General academic skills } & 1 & 0.420 & 0.658 \\ \text { Field-specific skills } & 0.420 & 1 & 0.266 \\ \text { Management skills } & 0.658 & 0.266 & 1\end{array}$

All correlations are significant at the 0.01 level (2-tailed)

We now turn to a comparison of the level of competences possessed at the time of graduation and the level of required competences in the current job position.

Table 3 gives a first insight into the extent to which the students possessed the competences at the time of graduation and to which extent these are required in the current job.

Table 3

Competences possessed at the time of graduation and competences required in current job

Time of graduation (1995) Current job (1998) Increase

\begin{tabular}{llllll} 
Whole population: & \multicolumn{3}{c}{ Whole Population } & Whole population \\
Academic Skills: & 3.6855 & Academic Skills: 3.8040 & Academic Skills: & $0.1185+$ \\
Field-specific Skills: & 3.3187 & Field-specific Skills: 3.4594 & Field-specific Skills: & $0.1407+$ \\
Management Skills: & 3.2444 & Management Skills: 3.8266 & Management Skills: & $0.5822+$
\end{tabular}

+ Indicates a significant (0.01 level) increase compared to the time of graduation

As the results in table 3 show, the extent to which the competences are required in the current job is significantly higher for all three groups than the extent to which the competences were present at the time of graduation. Considering the whole population and assuming that the extent to which the competences are required in the current job approximately indicates the level to which the competences are possessed, we can therefore conclude that our graduates did not stop learning after leaving university, but, either by working experience or by on- and off-the-job training, increased their competences level significantly. The increase is clearly highest with respect to management skills, indicating that management skills can be learned more efficiently in a working context.

Turning our attention to two different groups of respondents, namely those who were working in a job in their field-specific domain and those who were working in a job outside their field-specific domain, the following picture emerges. 
Table 4

Competences possessed at the time of graduation and competences required in the current job (splitup by working inside and outside one's own field-specific domain)
Time of graduation (1995)
Current job (1998)
Increase

1. Inside own domain

Academic Skills:

Field-specific Skills:

Management Skills:

2. Outside own domain

Academic Skills:

Field-specific Skills:

Management Skills:

3.7291
3.2864
3.2524

3.6606

3.3348

3.2396

1. Inside own domain

Academic Skills: $3.8587^{*}$

Field-Specific Skills: $3.6673^{*}$

Management Skills: $3.8644^{*}$

2. Outside own domain

Academic Skills:

$3.4322^{*}$

Field-Specific Skills: $2.5343^{*}$

Management Skills: $3.5255^{\star}$
1. Inside own domain

Academic skills: $\quad 0.1981+$

Field-specific skills: $\quad 0.3325+$

Management skills: $\quad 0.6248+$

2. Outside own domain

Academic skills: $\quad-0.2969-$

Field-specific skills: $\quad-0.7521-$

Management skills: $\quad 0.2731+$

* Indicates that the difference between inside and outside own domain is significant at 0.01 level.

$+(-)$ Indicates a significant $(0.01$ level) increase (decrease) compared to the time of graduation

The results in Table 4 confirm what was put forward in our theoretical notions above, namely that for graduates the use of their field-specific competences learned at the university is context-bound. For graduates finding their way into a position inside their field-specific domain during the first three years on the labour market, the current job context requires on average a level of knowledge of field-specific theories and methods significantly above the level that was built up during university education. After leaving university, graduates will therefore not only have to keep up their initial level of field-specific knowledge but will have to increase their level of field-specific knowledge, either by experience in their own domain and/or by further training. On the other side of the spectrum, graduates who are unable to find a job inside their domain will be confronted with a current job context in which the knowledge of field-specific methods and theories studied at the university plays a minor role. Not only is the required level of field-specific knowledge outside the domain significantly lower than inside it, but the level is also significantly lower than the one possessed at the time of graduation. Graduates working outside the domain will loose contact with new fieldspecific innovations and their knowledge of field-specific methods and theories will decrease. This will be the case in particular for studies in which the rate of innovation is both substantial and rapid. Furthermore, we find that working outside one's own domain does not require an increased level of general academic skills.

Turning our attention finally towards the distinction between supervisory and non-supervisory jobs, we are specifically interested in the question as to what extent the level of management competences required in the current job matches the level of management competences possessed at the time of graduation.

The results with respect to management competences clearly show that neither for managers nor for non-managers the level possessed at the time of graduation matches the required level in their current job position. Managers, as defined above, not only find themselves in a context in which they have to handle a larger required amount of management competences but also the increase to be handled within the first three years 
after graduation is larger, as they start from the same level as graduates who do not find their way in the middle- or top-level management after three years. This may indicate that management skills are acquired better in a context of work. Interestingly, we find that for managers - besides the required level of management competences - the required level of field-specific and general academic competences is also higher than for graduates without a supervisory job. With respect to the field-specific skills, this result can be based mainly on the fact that graduates working inside their domain have a greater probability of finding their way into the middle- or top-level management of a company than graduates working outside their domain. Therefore, the results have to be combined with the findings of Table $4 .{ }^{14}$ With respect to general academic skills, the result may indicate that the required investment into management skills also requires an increased level of general academic skills.

Table 5

Competences possessed at the time of graduation and competences required in the current job (splitup by holding either a management or a non-management position)

Time of graduation (1995)

Current job (1998)

Increase

1. Managers (Top and Middle)

Academic Skills:

3.6502

Field-specific Skills:

Management Skills:

3.3750

3.2359

2.Non- Managers

Academic Skills:

Field-specific Skills:

Management Skills:
3.7025

3.2763

3.2400
1. Managers (Top and Middle)

Academic Skills: $3.9482^{*}$

Field-Specific Skills: $3.7612^{*}$

Management Skills: $3.9356^{\star}$

2.Non- Managers

Academic Skills:

$3.7466^{*}$

Field-Specific Skills: $3.2981^{*}$

Management Skills: $3.7705^{\star}$
1. Managers (Top and Middle)

Academic skills: $\quad 0.2980+$

Field-specific skills: $0.3826+$

Management skills: $\quad 0.6997+$

2.Non- Managers

Academic skills: $\quad 0.0441$

Field-specific skills: $\quad 0.0218$

Management skills: $0.5305+$

* Indicates that difference between managers and non-managers is significant at 0.01 level.

+ Indicates a significant ( 0.01 level) increase compared to the time of graduation

The findings within this descriptive section are in general consistent with our theoretical notions presented above. In what follows, we turn to the question to what extent the level of our three competences clusters pays off and hence to the question to what extent obtaining those skills during university education directly or indirectly increases the productivity of graduates.

\section{The direct pay-off of human capital competences: A general wage regression}

In order to find out whether the level of human capital (general academic competences, fieldspecific competences and management competences) obtained during one's university education pays off, this section will try to explain the gross hourly wages measured three years after graduation on the basis of a number of characteristics, referring to person,

14. $43 \%$ of the graduates working inside their own field-specific domain hold a management position versus only $18 \%$ of the graduates working outside their field-specific domain. 
education, experience, job, organization in which the graduates work, and socio-economic background. We will examine to what extent the hypotheses presented in the introductory section, namely that graduates assigned to an occupation inside their field-specific educational domain have a comparative advantage and hence, that field-specific skills are of higher productive value inside one's own educational domain, and that management competences obtained in particular by experience and on-the-job training pay off, can be supported by empirical evidence.

We will start with a Mincerian wage equation estimation ${ }^{15}$ (see e.g. Mincer, 1974), in which the natural logarithm of the gross hourly wage is explained in a linear equation on the basis of a number of characteristics, referring to person, education, experience, job, the organization in which the graduates work three years after leaving the university, and socioeconomic background. As personal characteristics, the variables of gender and age were included in the analysis. The variable 'gender: male' is expected to have a positive effect on wages if employers discriminate against women due to, for example, the expected loss of human capital resulting from the interruption of working life to raise children. The variable 'age', measured in years at the time of the survey (1998), is expected to have a positive sign, because an increase is expected to have a positive effect on the graduate's amount of human capital and hence on the productive value. As all our graduates have the same level of diploma (laurea), we only use the field of study and an overall indication of the grades with which the students graduated, to indicate their education. Two indicators were used to characterize the working contract that the graduates possess, namely if they have a full-time job and if they have a permanent job. We expect a permanent contract to be positively related with the wages paid, but for graduates with a part-time contract the sign of the impact is not clear. Part-time workers may have a higher hourly productivity, but the organizational costs of part-time workers are also expected to be higher. Whereas the former argument may lead us to expect a positive impact on wages, the latter argument directs us in the opposite direction. Six types of job characteristics were used in the analysis. First, the variables whose effect on wages we try to estimate, being the level of 'general academic skills, 'field-specific skills' and 'management skills' required. In the second place, the match between job and education, indicated by the educational level and the field of study required for the job. On the basis of the job-matching theory, we expect that the better the match is, the higher the wages will be. Finally, a variable indicating if the graduates are working in a supervisory job (top- or middle-level management) is included. With respect to working experience, a difference was made between the experience inside the current job (measured in months) and the working experience between the graduation and the start of the current job. For both variables, we expect a positive sing, because longer working experience is expected to increase the level of human capital, but the additional increase is expected to decrease over time. Finally, three control variables are included, namely a dummy for graduates working for a private employer (in contrast to graduates working for either a public

15. We do not capture the skills or other characteristics of those graduates who do not manage or who do not choose to gain employment. We intend therefore to estimate in particular the impact of obtained skills conditional on gaining employment, and hence do not include the effect of acquired skills on the probability of being employed. 
employer or a non-profit organization), the number of employers worked for after graduation, and the education level of the parents (a dummy indicating if at least one of the parents has a tertiary-level education). For the dummy representing the education of the parents, we expect to find a positive sing, as higher educated parents may be able to provide their children with access to a network of better jobs on the labour market. The wage equation to be estimated takes the following form

(1) $\ln \left(w_{i}\right)=\alpha_{1}+\alpha_{2} S_{r 1 i}+\alpha_{3} S_{r 2 i}+\alpha_{4} S_{r 3 i}+\alpha_{5} X_{i}+\varepsilon_{i}$

where In $\left(w_{i}\right)$ is the natural log gross hourly wage of individual $i, S_{r 1 i}, S_{r 2 i}$ and $S_{r 3 i}$ are the required levels of general academic skills, field-specific skills and management skills, respectively, in the occupation held by individual $i, X_{i}$ is a vector of variables other than $S_{r y i}$ (with $y=1,2$ or 3 ) that influence wages (e.g. field of study, gender or years of experiences) and $\varepsilon_{\mathrm{i}}$ is an error term statistically independent of $\mathrm{S}_{\mathrm{rji}}$ and $\mathrm{X}_{\mathrm{i}}$.

The results of the wage analysis (see Table 6) show that, if one controls for the variables discussed above, the only type of human capital competences paying off are 'management competences'. As a matter of fact, the required level of management competences even pays off if one controls for having a supervisory (top- and middle-level management) position. Independently of having a supervisory job or not, an increase of the required management competences by 1 point leads to an increase of the hourly wages by $11.6 \%$. With respect to the other two human capital competences 'general academic skills' and 'field-specific skills', the wage analysis shows that the required level does not have a significant effect. For field-specific competences the influence may be taken over by the dummy for working inside the own domain. Excluding this dummy, however, does not change the results qualitatively. Replacing the required level of human capital competences by the level possessed at the time of graduation yields the results that none of the human capital competence levels has a direct impact on gross hourly wages. ${ }^{16}$

Having established that the required level of 'management skills and a good match between education and work (working inside the domain) have a direct positive impact on gross hourly wages, we intend to examine in the following two subsections to what extent the level of 'general academic skills and 'field-specific skills' possessed at the time of graduation indirectly explains the wage rate. In our theoretical notions, we have put forward that general academic competences are of specific importance as a basis for further learning and as a basis upon which graduates can fall back in a context in which their field-specific competences are not used. With respect to field-specific competences possessed at a specific moment in time, we will try to examine to what extent these influence the allocation over jobs inside and outside one's own educational domain and thus indirectly the wage rate at that moment of time (the results in Table 6 show that working inside one's domain increases gross hourly wages by $14 \%$ ).

16. Results are not shown in this paper. 
Table 6

Linear regression analysis of the gross hourly wages (In)

Coefficient

t-value

Personal characteristics

Gender: male

0.0766

1.650

Age at time of survey (1998)

0.006064

0.736

Competences required in current job

General academic skills

$-0.04927$

$-0.849$

Field-specific skills

$-0.02934$

$-1.263$

Management skills

0.110

$2.290^{*}$

Education

Health (reference)

Arts \& Humanities

$-0.0755$

$-0.671$

Social Sciences

0.03264

0.295

Business

0.162

1.643

Law

0.01226

0.100

Natural Sciences

$-0.09382$

$-0.873$

Engineering

0.0735

0.742

Grade at graduation

0.04616

0.997

Job characteristics

Full-time contract

$-0.04815$

$-0.655$

Permanent contract

0.259

$4.616^{* \star}$

Job at university level

0.05149

1.027

Job in own domain

0.131

$1.949^{*}$

Supervisory job

0.09352

$1.962^{*}$

Working experience

Experience inside current job (months)

Experience inside current job (months) ${ }^{\wedge} 2$

$-9.356 \mathrm{E}-4$

$-0.411$

Total working experience (months)

4.267E-6

0.276

Total working experience (months) ${ }^{\wedge} 2$

0.00709

0.635

5.913E-7

0.035

Organization characteristics

Private sector

0.02832

0.551

Number of employers after graduation

0.004947

0.419

Parent's highest education: tertiary education

0.07409

1.080

Constant

1.374

4.150 **

\begin{tabular}{lll}
\hline R-squared $=0.19$ & S.E. $=0.4611$ & ${ }^{*}$ significant at the $5 \%$ level \\
$F=4.960^{* * *}$ & $N$ cases $=532$ & ${ }^{* *}$ significant at the $1 \%$ level
\end{tabular}

For this reason, Section 5 will first examine to what extent the required level of management competences, which has a significant positive impact on gross hourly wages, can be explained by the amount of the three different human capital competences possessed at the time of graduation. In particular, we will estimate to what extent 'general academic skills obtained at university are of supportive importance to learn the 'management skills' for which the labour market clearly seems to pay. Secondly, we will examine to what extent the odds of working inside one's own field-specific educational domain, which has a significant 
positive impact on gross hourly wages, can be traced back to the level of human capital possessed at time of graduation, and in specific to the amount of field-specific competences. We will concentrate on the odds of working inside one's own field-specific educational domain, instead of the required level of field-specific competences, as the latter seems not to have a significant positive impact on the wage rate. ${ }^{17}$

\section{The indirect pay-off of human capital competences}

\section{The indirect pay-off of general academic competences}

In order to find out whether the level of general academic competences can partially explain the level of required 'management skills', a linear equation was estimated in which the level of required 'management skills' in the current job is explained on the basis of a number of characteristics, referring to person, education, experience, job, and the organization in which the graduates work. As we intend to explain the 'management skills' requirements of the current job, it is of importance to include in our analysis as many different ways in which those competences may have been established as possible. In addition to the fact that human capital competences are obtained during university education, we must therefore also include the impact of experience in a supervisory position and the possible effect of onthe-job or off-the-job training after graduation. The other control variables are identical to the ones included in the wage regression in the previous section. The equation to be estimated takes the following form:

(2) $S_{r 3 i}=\beta_{1}+\beta_{2} S_{e 1 i}+\beta_{3} S_{e 2 i}+\beta_{4} S_{e 3 i}+\beta_{5} X_{i}+\eta_{i}$,

where $S_{r 31}$ is the required level of management skills, $S_{e 1 i}, S_{e 2 i}$ and $S_{e 3 i}$ are the levels of general academic skills, field specific skills and management skills, respectively, obtained during one's university education, $X_{i}$ is a vector of variables other than $S_{\text {eyi }}$ (with $y=1,2$ or 3 ) that influence the required level of management skills (e.g. training after graduation, working inside the field-specific domain), and $\eta_{i}$ is an error term statistically independent of $S_{\text {eyi }}$ and $X_{i}$.

Assuming that the required level of 'management skills' indicates correctly the level that the graduates have to handle and thus approximately the level that the graduates possess at that time, we can interpret the results of the analysis in Table 7 as follows. For our analysis, four variables are of particular interest in the context of explaining the required level of 'management competences'. Firstly, working in a supervisory job has the expected positive effect on the requirement. In contrast to graduates in non-supervisory jobs, graduates in supervisory jobs can learn and increase their management competences by experience. Secondly, the level of management competences possessed at the time of graduation has a

17. As graduates working in their own field-specific domain on average have to handle a significantly higher level of field-specific skills than graduates working outside their field-specific domain (see Table 4), we will indirectly also discuss the impact of the level of field-specific skills obtained in education on the required level. 
positive and significant impact on the required level. The effect is thereby smaller than the effect of post-graduate management training (on-the-job or-off-the-job training) indicating that management competences are acquired more effectively in the context of work. Thirdly, the level of 'general academic skills possessed at the time of graduation has the expected significant positive sign. Therefore, the general academic competences play their role as supportive competences upon which graduates can fall back, as predicted by our theoretical notions.

Table 7

Linear regression analysis of the required level of management competences in the current job

\begin{tabular}{llr}
\hline & Coefficient & t-value \\
\hline Personal characteristics & & -0.280 \\
Gender: male & & -1.195 \\
Age at time of survey (1998) & -0.01698 & $2.448^{*}$ \\
Competences possessed at time of graduation & -0.01304 & 0.671 \\
General academic skills & & $1.963^{*}$ \\
Field-specific skills & & 0.185 \\
Management skills & 0.02278 & 0.120 \\
\end{tabular}

Education

Health (reference)

Arts \& Humanities

0.190

Social Sciences

0.307

0.171

1.277

Business

0.09778

列

Law

0.0734

Natural Sciences

0.120

1.320

Engineering

Grade at graduation

0.09167

0.609

0.517

0.915

1.496

Training after graduation

Cross-disciplinary training

$0.052688 \quad 0.688$

Field-specific training

$-0.222$

$-1.774$

Management training

0.332

Job characteristics

Full-time contract

0.09935

1.026

Permanent contract

0.05207

0.709

Job at university level

0.311

$4.883^{* *}$

Job in own domain

0.09213

1.085

Supervisory job

0.226

$3.614^{* *}$

Working experience

Experience inside current job (months)

0.001523

0.508

Experience inside current job (months) ^ 2

$-5.559 \mathrm{E}-6$

$-0.272$

Total working experience (months)

$-0.001998$

$-0.559$

Total working experience (months) ${ }^{\wedge} 2$

7.851E-6

0.355

Number of employers after graduation

$-0.003684 \quad-0.239$

Parent's highest education: tertiary education

0.003859

0.044

Constant

2.319

$5.005^{* *}$

\begin{tabular}{lll}
\hline R-squared $=0.199$ & S.E. $=0.6064$ & ${ }^{*}$ significant at the $5 \%$ level \\
$F=4.672^{* *}$ & $N$ cases $=534$ & ${ }^{* *}$ significant at the $1 \%$ level
\end{tabular}


The analysis carried out above supports the hypothesis that general academic competences acquired during university education pay off, although these seem not to play a direct role in explaining gross hourly wages. To clarify this indirect link even further, we will derive mathematically an equation linking the level of competences possessed at the time of graduation directly to the gross hourly wages measured three years after graduation. As the two analyses above are both linear, we will simply substitute the equation for the required level of management competences (2) in the equation explaining the gross hourly wages (1). For simplicity reasons, any non-significant coefficients of one of the two analyses above are excluded from the table below.

Table 8

Substituted linear gross hourly wage (In) equation

\section{Coefficient}

Competences possessed at time of graduation

General academic skills

0.02035

Management skills

0.01332

Education

Health (reference)

Social Sciences

Training after graduation

Management training

Job characteristics

Permanent contract

0.259

Job at university level

0.03421

Job in own domain

0.131

Supervisory job

0.11838

Constant

1.62909

The results of the substituted wage equation analysis in Table 8 show that our first step analysis (see Table 6) clearly underestimates the impact of 'general academic competences' obtained in university education, as it neglects the supportive role that those competences can play once the graduates have left university. The above results indicate that general academic competences possessed at the time of graduation have a positive effect on gross hourly wages. A 1-point increase of these increases wages by approximately $2.0 \%$ even if one controls for the variables discussed above.

Our analysis has therefore shown that 'general academic skills' obtained during a higher educational career are paid for by the labour market, albeit through their supportive role rather than through a direct productivity increasing factor. These skills help graduates manage situations in which their management competences learned at university are either not directly applicable or have not been obtained to a sufficient level. General academic competences therefore play an important supportive role that is also acknowledged by the labour market. 
Having established a direct link between the management competences required in the current job and the gross hourly wages paid, and an indirect link between both management competences and general academic competences possessed at the time of graduation and the gross hourly wages, we will analyze in the following section to what extent field-specific competences possessed at the time of graduation determine the allocation of graduates over jobs inside and outside their own domain when leaving university, and the allocation realized three years after graduation.

\section{The indirect pay-off of field-specific competences}

The results of the wage analysis carried out in Section 4 show that the level of field-specific competences required in the current occupation does not influence the pay-off directly. Following the same analytical path as in the last section therefore yields no success. Our general wage regression incorporated the educational domain required for the current job. The findings confirmed the idea that working inside one's own field-specific educational domain creates a comparative advantage and hence is better paid. Graduates working inside their own field-specific educational domain are not only better paid (see Table 6) but are also required to handle a higher level of field-specific skills (see Table 4). Hence, the following analysis on the odds of finding an occupation inside one's own field-specific domain also discusses indirectly the impact of human capital competences obtained at school on the required level of field-specific skills.

Graduates leaving university education will be allocated to jobs inside and outside the educational domain. Although our focus is on the work situation three years after graduation, the initial allocation is of importance and may to a large part determine this situation. In what follows, we will work in two steps. By means of logistic regression, we first try to estimate whether field-specific competences learned at university are of importance in explaining the odds of working inside the educational domain immediately after graduation, and secondly, we will estimate to what extent the initial allocation determines the current situation (measured three years after graduation)

As the data do not provide us with precise information on the domain in which graduates find their first jobs after graduation, we can only approach the issue in our first step. Fortunately, the data provide us with information on the importance of different aspects for the employer in recruiting the graduates for their initial employment after graduation. ${ }^{18}$ We will concentrate on the answers to the question "importance of main subject/specialization". Assuming that the main subject/specialization is only inside one's field-specific domain of importance, we approximate finding a job inside the domain by graduates answering that the main subject/specialization was important or very important for their first employer when recruiting them. By means of logistic regression, we estimate whether the amount of field-specific competences possessed at the time of graduation has a significant impact on the probability

18. The precise question is: How important, according to your perception, were the following aspects for your employer in recruiting you for your initial employment after graduation (measured on a 5point scale from 1 "not important at all" to 5 "very important"). 
of finding the initial job inside one's own domain. We control for the level of general academic skills and management skills possessed at the time of graduation, for the field of study, and for personal characteristics (gender and age at the time of graduation). Formally, the probability of working inside one's own domain immediately after graduation is given by

(3) $P\left(D_{s i}\right)=\left(e^{f(D s i)}\right) /\left(1+e^{f(D s i)}\right)$

where $P\left(D_{\text {si }}\right)$ is the probability of individual $i$ working inside his or her own domain immediately after graduation and

(4) $f\left(D_{s i}\right)=\gamma_{1}+\gamma_{2} S_{e 1 i}+\gamma_{3} S_{e 2 i}+\gamma_{4} S_{e 3 i}+Y_{5} X_{i}+\phi_{i}^{19}$

where $X_{i}$ is a vector of variables that influence the probability of working inside one's own domain (e.g. the field of study), and $S_{e 11}, S_{e 2 i}$ and $S_{e 3 i}$ represent the obtained level of general academic, field-specific, and management skills, and $\phi_{\mathrm{i}}$ is an error term with the usual characteristics.

The results in Table 9 indicate that the probability of finding a first job in which the main subject/specialization is of great importance (resembling a job inside the field-specific domain), depends on the level of field-specific competences possessed at the time of graduation, even if one controls for personal characteristics and the field of study.

So far, we have been able to show that the level of field-specific competences possessed at the time of graduation is of importance for the allocation of graduates to different initial jobs. What is missing is a link between the initial allocation and the allocation found three years after graduation. To achieve this, we will estimate whether graduates have jobs that optimally match their qualifications three years after graduation. We will include in the logistic regression analysis not only the level of general academic, field-specific and management competences possessed at the time of graduation but, in addition to any training received after graduation, also the probability of having found the initial job inside or outside one's own domain. For controlling reasons, some personal characteristics (age and gender), the field of study, the number of jobs after graduation until the moment of the survey, the months of experience inside the current job, and the months of total working experience, are also included in the analysis. Formally, the probability of currently working inside one's own domain can be written as:

(5) $P\left(D_{c i}\right)=\left(e^{f(D c i)}\right) /\left(1+e^{f(D c i)}\right)$

where $P\left(D_{c i}\right)$ is the probability of currently working inside one's own field-specific domain, and

(6) $f\left(D_{\text {ci }}\right)=\delta_{1}+\delta_{2} S_{e 1 i}+\delta_{3} S_{e 2 i}+\delta_{4} S_{e 3 i}+\delta_{5} S_{i}+\delta_{6} X_{i}+\mu_{i}$

19. $f\left(D_{s i}\right)$ is equal to $\ln \left[P\left(D_{s i}\right) /\left(1-P\left(D_{s i}\right)\right)\right]=$ log odds ratio. 
where $X_{i}$ is a vector of variables that influence the probability of working inside one's own domain (e.g. the field of study), $S_{e 1 i}, S_{e 2 i}$ and $S_{e 3 i}$ represent the obtained level of general academic, field-specific, and management skills, $S_{i}$ is a dummy that is 1 if the respondent was working inside his or her own educational domain immediately after graduation, and otherwise 0 and $\mu_{i}$ is an error term with the usual characteristics.

Table 9

Results of logistic regression with dependent variable working inside ones educational domain immediately after graduation

Coefficient

Personal characteristics

Gender: male

Age at time of graduation

Competences possessed at time of graduation

General academic skills

Field-specific skills

Management skills

Education

Health (reference)

Arts \& Humanities

Social Sciences

Business

Law

Natural Sciences

Engineering

Constant
S.E.

$\begin{array}{rl}0.188 & 0.195 \\ -0.111 & 0.042^{*}\end{array}$

$\begin{array}{rl}0.085 & 0.255 \\ 0.323 & 0.116^{*} \\ -0.104 & 0.206\end{array}$

$\begin{array}{ll}-0.577 & 0.438\end{array}$

$\begin{array}{ll}-0.084 & 0.467\end{array}$

$\begin{array}{ll}-0.273 & 0.408\end{array}$

$-0.654 \quad 0.571$

$\begin{array}{ll}-0.085 & 0.434\end{array}$

$0.379 \quad 0.406$

$1.341 \quad 1.406$

\begin{tabular}{ll}
\hline-2 Log likelihood $=710.964$ & Chi-square $=34.362^{*}$ \\
$\mathrm{~N}$ cases $=567$ & $*$ Significant at the $1 \%$ level
\end{tabular}

The results of the above logistic regression show that, even after controlling for the variables mentioned above, the domain of the initial job after graduation has a significant positive influence on the log-odds ratio of working inside one's own field-specific domain three years after graduation. As we have controlled for the number of jobs that graduates had in the first three years after graduation, the impact of the initial job is cleaned from the fact that graduates who find their initial job inside the domain may not change the job as often as graduates who start working outside their domain. ${ }^{20}$

20. This is also tested by comparing the number of employers one had in the first three years. Graduates starting their working career inside their field-specific domain had on average 2.35 employers compared to an average of 2.50 employers for graduates who started outside their domain (the F-statistic of 0.879 indicates that the averages of the two groups do not differ significantly). 
Table 10

Results of logistic regression with the dependent variable working inside one's educational domain three years after graduation

Personal characteristics

Gender: male

$0.279 \quad 0.295$

Age at time of graduation

Competences possessed at time of graduation

General academic skills

$\begin{array}{rr}-0.160 & 0.380 \\ 0.098 & 0.157 \\ 0.219 & 0.314\end{array}$

Field-specific skills

0.219

0.314

Education

Health (reference)

Arts \& Humanities

$-7.642$

9.938

Social Sciences

$-6.763$

Business

$-5.876$

9.938

Law

$-6.155$

9.950

Natural Sciences

$-6.713$

9.939

Engineering

Initial job after graduation

Inside own domain

Training after graduation

Cross-disciplinary training

Field-specific training

Management training

0.673

0.775

\section{Working experience}

Experience inside current job (months)

$\begin{array}{ll}-0.001 & 0.022\end{array}$

Experience inside current job (months) ${ }^{\wedge} 2$

0.000

0.000

Total working experience (months)

Total working experience (months) ${ }^{\wedge} 2$

$-0.014$

0.023

Number of employers after graduation

0.000

0.000

Constant

0.095

0.111

6.377

10.165

\begin{tabular}{ll}
\hline-2 Log likelihood $=368.523$ & Chi-square $=66.476$ \\
$N$ cases $=506$ & $*$ Significant at $1 \%$ level
\end{tabular}

Combining the results of this part we can therefore conclude that, in line with the jobmatching theory, it pays off for graduates to work in jobs that match their education three years after leaving university. Although the level of field-specific competences either required for the job or possessed at the time of graduation does not pay off directly, we found that the odds of having a job inside one's own domain depends greatly on the level of field-specific competences built up during university education, as it influences the initial allocation of graduates to the jobs available. 


\section{Conclusions}

In this paper, we examined the different roles and pay-offs in the labour market of three different types of human capital competences, namely 'general academic skills', 'fieldspecific skills' and 'management skills'. We argued that university education produces a mix of all three types of human capital, in which the 'field-specific skills' play a central role.

We have found that management competences are demanded in the labour market and investing in the acquisition of these pays off. We also found some evidence that management competences are acquired more effectively in the context of work, either by experience in a supervisory job or by on-the-job or off-the-job training, than in the context of the field-specific guided university education.

With respect to the 'general academic skills' obtained by university education, we found that they seem not to pay off directly, as a simple empirical analysis could not produce a significant impact of 'general academic skills' on gross hourly wages. Building upon the theoretical notions, we showed that 'general academic skills' play a major supportive role, instead of a direct productivity increasing one. The level of 'general academic skills' acquired by university education positively influenced the level of 'management skills' required three years after graduation and hence, indirectly the wage level of graduates.

With respect to 'field-specific skills', as was in the case with 'general academic skills', we could neither establish a direct link between the level obtained by university education and the gross hourly wages paid three years after graduation, nor between the required level of 'field-specific skills' and the wage rate. As the pay-off of 'field-specific competences' is strongly context-bound (wages are significantly higher if one holds a position inside one's own field-specific domain where the use of field-specific skills is significantly larger), we examined to which extent the level of 'field-specific competences' obtained by initial education can explain the allocation of graduates to positions inside and outside the domain. We found that the level of 'field-specific competences' possessed at the time of graduation can partially explain the initial allocation but not the allocation found three years later. Our empirical research also pointed out that the allocation of first jobs can explain to a large extent the situation three years later. Hence, the impact of 'field-specific competences' obtained by university education on the wages paid three years after, is partially through the initial allocation of graduates to jobs inside and outside the field-specific domain.

Concluding we can state that:

- Field-specific competences obtained at university influence the initial allocation on the labour market, which determines the current allocation to jobs inside and outside one's own educational domain. As jobs inside one's own field-specific domain are better paid than jobs outside one's own domain, investment in field-specific competences indirectly pays off.

- Management competences are directly valued in the labour market, but seem to be more effectively acquired in a working context than at university.

- General academic competences obtained at university have a significant supportive role as a basis upon which graduates can fall back to train especially those skills (e.g. 
management skills) that can be acquired more effectively outside education. General academic competences therefore only pay off indirectly.

Summarizing, the lesson we learned from this explorative exercise is that:

- It is dangerous to derive directly from wages, which skills should be taught in initial education.

- Instead, the entire process of learning, from initial education to work, should be considered in order to find out which skills can be generated most effectively at which stage.

- In analyzing the skills to be taught, one has to take into consideration the fact that general academic skills may not have a direct pay-off in the labour market. Conversely, their pay-off may be indirectly of crucial importance for the efficiency with which the skills required in the job are generated.

We should point out, however, that the research findings concern university graduates from Northern Italy and more specifically graduates in the very early stages of their careers. It would be desirable to include other educational levels, graduates from other countries and later stages in their careers to test for the generality of our findings. Furthermore, it would be of interest to include other types of human capital competences in the analysis.

\section{References}

Allen, J., van der Velden, R. (2001), Educational mismatches versus skill mismatches: effects on wages, job satisfaction and on-the-job search, Oxford Economic Papers, 53 (3), 434-452.

Altonji, Joseph G. (1995), The Effects of High School Curriculum on Education and Labor Market Outcomes, Journal of Human Resources, 30 (4), 409-438.

Bartel, A.P., N. Sicherman (1998), Technological Change and the Skill Acquisition of Young Workers, Journal of Labor Economics, 16 (4), 718-755.

Becker, G.S. (1962), Investment in human capital: a theoretical analysis, The Journal of Political Economy, 70 (5), supplement, 9-49.

Becker, G.S. (1964), Human capital: a theoretical and empirical analysis with special reference to education, New York: NBER.

Bennett, N., Dunne, E., Carré, C. (1999), Patterns of core and generic skill provision in higher education, Higher Education, 37, 71-93.

Bishop J.H. (1995), Vocational education and at-risk youth in the United States, Vocational Training European Journal, 6 (September - December), 34-42.

Bowen. H.R. (1977), Investment in Learning, San Francisco: Jossey-Bass Inc.

Brunello, G., Comi, S., Lucifero, C. (2000), The Returns to Education in Italy: A New Look at the Evidence, IZA Discussion paper no. 13, Bonn.

Campbell, P.B., Laughlin, S. (1991), Participation in Vocational Education: An Overview of Patterns and Their Outcomes, Columbus, Oh: National Centre for Research in Vocational Education.

Ducatel, K. (1998), Learning and skills in the Knowledge Economy, Danish Research Unit for Industrial Dynamics, Working Paper No. 98-2, Aalborg.

Duncan, B. (1968), Trends in Output and Distribution of Schooling, in Sheldon, E.B., Moore, W.E. (Eds.), Indicators of Social Change, New York: Russell Sage Foundation. 
Green, F. (1998), The value of skills, Department of Economics University of Kent, Studies in Economics Series, Kent.

Green, F. Ashton, D., Felstead, A. (2001), Estimating the determinants of supply of computing, problem-solving, communication, social, and teamworking skills, Oxford Economic Papers, 53 (3), 406-433.

Hartog, J. (1992), Capabilities, allocation and earnings, Dordrecht: Kluwer Academic Publishers.

Heijke, H., Koeslag, M., van der Velden, R. (1998), Education, Skills and Wages, in Heijke, H., Borghans, L. (eds.), Towards a Transparent Labour Market for Educational Decisions, Aldershot, U.K.; Brookfield, Vt. and Sydney: Ashgate.

Heijke, H., Ramaekers, G. (1998), The knowledge and skills of economics graduates and their significance on the labour market, in: Nijhof, W., Streumer, J. (eds.), Key Qualifications in Work and Education, Dordrecht: Kluwer Academic Publishers.

Heijke, H., Ramaekers, G. (paper presented at EALE conference 2001, Jyväskylä, Finland), On management skills of young economists: Where they are learned, and does management pay off?, Research Centre for Education and the Labour Market, Maastricht.

Johnson, W.R. (1979), The Demand for General and Specific Education with Occupational Mobility, Review of Economic Studies, 46, 695-705.

Kang, S., Bishop, J. (1989), Vocational and Academic Education in High School: Complements or Substitutes?, Economics of Education Review, 8 (2), 133-148.

Levhari, D., Weiss, Y. (1997), The Effects of Risk on the Investment in Human Capital, American Economic Review, 64, 950-963.

Mane, F. (1999), Trends in the Payoff to Academic and Occupation-Specific Skills: The Short and Medium Run Returns to Academic and Vocational High School Courses for Non-College-Bound Students, Economics of Education Review, 18, 417-437.

Mclntosh, S., Vignoles, A. (2001), Measuring and assessing the impact of basic skills on labour market outcomes, Oxford Economic Papers, 53 (3), 453-481.

Mincer, J. (1974), Schooling, Experience and Earnings, New York: Columbia University Press.

Moscati, R., Rostan, M. (2000), Higher Education and Graduate Employment in Italy, in Higher Education and Graduate Employment, European Journal of Education, Research, Development and Policies, 35 (2), 201-209.

Nunnually, J.C., 1978, Psychometric theory, $2^{\text {nd }}$ edition, New York: McGraw-Hill.

O'Shaughnessy, K.C., Levine, D.I., Cappelli, P. (2001), Changes in managerial pay structures 19861992 and rising returns to skill, Oxford Economic Papers, 53 (3), 482-507.

Quinn, R.E. et al. (1990), Becoming a master manager: a competence framework, New York: John Wiley \& Sons.

Sattinger, M. (1993), Assignment Models of the Distribution of Earnings, Journal of Economic Literature, 31 (June), 831-880.

Schultz, T.W. (1961), Investment in human capital, The American Economic Review, 11, 1-17.

Sluis, E.C. van der (2000), De loopbaan als hindernisbaan, Economisch Statistische Berichten, 4, 312-314.

Smoorenburg van, M.S.M., van der Velden, R. (2000), The training of school-leavers, Complementarity or substitution?, Economics of Education Review, (19), 207-217.

Spenner, K. (1990), Skill: Meanings, Methods, and Measures, Work and Occupations, 17 (4), 399421.

Stasz, C., Ramsey, K., Eden, R., DaVanzo, J., Farris, H., Lewis, M. (1993), Classrooms that Work: Teaching Generic Skills in Academic and Vocational Settings, MR-169-NCRVE/UCB, RAND, Santa Monica, CA. 
Stasz, C. (1998), Generic skills at work: implications for occupationally-oriented education. In W.J. Nijhof \& J.N. Streumer (Eds.), Key Qualifications in Work and Education, Dordrecht: Kluwer Academic Publishers.

Stasz, C. (2001), Assessing skills for work: two perspectives, Oxford Economic Papers, 53 (3), 385405.

Thurow, L.C. (1975), Generating inequality, New York: Basic Books.

Welch, F. (1970), Education in Production, Journal of Political Economy, 78 (1), 35-59. 